\section{Performance and Economic Viability of Broiler Chickens Fed with Probiotic and Organic Acids in an Attempt to Replace Growth-Promoting Antibiotics}

-Author(s)

Araujo RGAC (iD https://orcid.org/0000-0002-1530-3886 Polycarpo GV' (D) https://orcid.org/0000-0001-6282-3297 Barbieri A' (ID) https://orcid.org/0000-0003-3935-6461 Silva KM ${ }^{\prime}$ (D) https://orcid.org/0000-0001-8822-193X Ventura G' (D) https://orcid.org/0000-0002-9790-3198 Polycarpo VCC' (D) https://orcid.org/0000-0003-3180-6042

College of Technology and Agricultural Sciences, UNESP-University Estadual Paulista-Campus of Dracena, Rod. Cmte., João Ribeiro de Barros, km651, Dracena-SP, 17900-000, Brazil.

\section{Mail Address}

Corresponding author e-mail address Robert Guaracy Aparecido Cardoso Araujo Rod. Cmte., João Ribeiro de Barros, km651, Dracena-SP, 17900-000, Brazil.

Phone: (55 18) 3821-8200

Email: robertzootecnista@gmail.com

\section{Eeywords}

Acetic acid, avilamycin, butyric acid, lactic acid, monensin sodium

\section{ABSTRACT}

The aim of this study was to evaluate diets supplemented with probiotic (Bacillus amyloliquefaciens) and organic acids (lactic, acetic and butyric acid) in attempt to replace the antibiotics and anticoccidial (avilamycin + sodium monensin) growth promoters on performance and economic viability of broilers challenged by Eimeria acervulina, $E$. maxima and $E$. tenella. A total of 900 male $\mathrm{Cobb}^{\circledR}$ chickens, with a mean weight of $39.90 \mathrm{~g}$, were distributed in a completely randomized design in a $2 \times 2+1$ factorial arrangement: supplementation or not of probiotic and organic acids and a treatment with inclusion of antibiotics, comprising five treatments with six replicates. For the studied performance variables, there was no effect of the isolated additives and no interaction between them $(p>0.05)$. Only the antibiotics promoted better results for weight gain (WG), feed intake (FI) and feed conversion rate (FCR). Therefore, the use of organic acids and probiotic, isolated or associated, provided lower performance to those receiving antibiotics, not improving the performance of chickens under the imposed challenge conditions. The highest revenues were generated with the use of antibiotics, providing greater profits.

\section{INTRODUCTION}

In broiler production, the main aim is to obtain productivity with satisfactory results of zootechnical performance. It is always followed by an economic analysis as food occupies a prominent place for being one of the factors that most demands costs, representing around $80 \%$ of the capital spent (Rufino et al. 2015). Thus, increasing feed efficiency using additives can help reduce costs by increasing the profitability of this production system.

The use of antibiotics as a growth promoter shows that their use in broiler nutrition is extremely important to maintain the types and quantity of bacteria in the digestive tract, as well as to form adequate protection to the wall of the intestinal mucosa, thus, to which enables a better utilization of the nutrients (Gonzales, Mello, Café, 2012; Shawkat et al. 2015). Their use has been pointed out as one of the possible causes of the increase in bacterial resistance, intensifying discussions based on the possibility of the presence of residues of animal origin in food that could harm the consumer's health. There is also the likelihood of an increase in microbial resistance, which can lead to problems in antibiotic treatments in humans, raising the attention of research to overcome such issues (Kelley et al. 1998; Sorum \& Sunde, 2001; Roe \& Pillai, 2003; Silva et al. 2010).

In 2006, the European Union chose to ban antibiotic use in animal feed (Langhout, 2000; Huyghebaert et al. 2011) and, this way, some diseases related to enteritis, such as coccidiosis, worsened on farms 
Araujo RGAC, Polycarpo GV, Barbieri A, Silva KM, Ventura G, Polycarpo VCC
Performance and Economic Viability of Broiler Chickens Fed with Probiotic and Organic Acids in an Attempt to Replace Growth-Promoting Antibiotics causing the broilers to have performance loss (Kipper et al. 2013).

Probiotics can be used to replace antibiotics, since they are dietary supplements composed of live and non-pathogenic microbial agents that benefit host health through intestinal balance (Loddi et al. 2000a; Kaur et al. 2002; Mountzouris et al. 2007; Sanders, 2008; Kabir, 2009; Ayasan, 2013). The organic acids, on the other hand, show specific antimicrobial activity with additional effects, including the $\mathrm{pH}$ reduction at the moment of digestion, trophic effects on the gastrointestinal tract mucosa, and increase of pancreatic secretion (Dibner \& Buttin, 2002; Van Immerseel et al. 2006; Kim \& Kim, 2015). Thus, it is greatly important that the animals' performance be quantified in order to evaluate the effects of eventual substitutions; however, the comparison among additives must be followed by an economic analysis to clarify the feasibility of using each one in the production systems.

Therefore, the aim of this study was to evaluate diets supplemented with probiotics and/or organic acids in an attempt to replace growth-promoting antibiotics on zootechnical performance and economic viability in broiler production.

\section{MATERIAL AND METHODS}

The experiment was conducted in accordance with the principles and regulations of the ethics committee on animal use - CEUA - of São Paulo State University, UNESP, Dracena Campus (Protocol n²6, 2013).

A total of 900 one-day-old male Cobb ${ }^{\circledR}$ chicks with an initial weight of $39.99 \mathrm{~g}$ were housed in thirty floor pens $\left(2.5 \mathrm{~m}^{2}\right)$ with first used wood-shavings beddings where they remained until 42 days of age. The chicks were distributed in a completely randomized design in a $2 \times 2+1$ factorial design: probiotic supplementation or not, organic acid supplementation or not, and a positive control treatment with inclusion of avilamycin + sodium monensin, comprising five treatments and six replicates of 30 broilers per experimental unit. The treatments were: diet without additives, diet with probiotic inclusion, diet with organic acid inclusion, diet with probiotic and organic acid inclusion, and diet with avilamycin + sodium monensin inclusion.

The probiotic used was Bacillus amyloliquefaciens $\left(1 \times 10^{9} \mathrm{CFU} / \mathrm{g}\right), 1 \mathrm{~kg} / \mathrm{t}$ addition. The organic acid blend consisted of lactic acid (40\%), acetic acid (7\%), and butyric acid (1\%), $8 \mathrm{~kg} / \mathrm{t}$ addition. The antibiotic used was $20 \%$ avilamicin with $50 \mathrm{~g} / \mathrm{t}$ addition, and the anticoccidian was $40 \%$ sodium monensin 300 g/t addition, allowing 10 to 120 ppm of the active principle.

The water and feed supply were ad libitum. The feeding program was divided into four phases: prestarter ( 1 to 7 days), starter (8 to 21 days), grower (22 to 34 days), and final (35 to 42 days). The rations were isoenergetic, isoproteic, and based on corn and soybean meal according to the recommendations of Rostagno et al. (2011) (Table 1).

Williams (1999, 2005), coccidiosis has caused economic losses in the poultry industry. Thus, three species of eimerias (E. Maxima, Tenella and Acervulina) were chosen because they are the ones that most affect the broiler production (Shirley et al. 2004). At 10 days of age, each broiler individually was orally inoculated with $1 \mathrm{ml}$ solution of $2 \times 10^{5}$ sporulated oocysts/ml Eimeria acervulina and $2 \times 10^{4}$ sporulated oocysts/ml E. maxima and E. tenella.

Lighting was constant, and temperature and ventilation were manually controlled by moving the side curtains. Temperature monitoring was performed daily, three times a day (at 8:00am, 12:00pm, and 5:00pm), by using a set of maximum-minimum thermometers.

At day 42 , the following performance variables were analyzed: weight gain (calculated by the difference between the weight of the broilers at the end of each period and the weight at housing), feed intake (obtained by the difference between the total feed supplied and the remainder collected at the end of each period), feed conversion ratio (calculated as the ratio of total feed intake and the weight gain, corrected for dead weight), and viability (expressed as percentage, 100 - mortality).

In the economic study, the feed cost, gross income, operating profit, profitability index, and the final cost/broiler were evaluated according to the method described by Lana (2000).

The profitability indicators used in this study were those considered by Martin et al. (1997): gross income, which is the total kilogram obtained by the treatment multiplied by the average unit price of broiler paid to producers; operating profit, which refers to the difference between the gross income and the total cost of the production; and profitability index, which is total profit divided by the total income, then multiplied by 100 .

The cost of each experimental diet was calculated with the prices of the ingredients based on the performance data of the animals throughout the experimental period and based on the price of January 2018, during which the economic analysis was 
Table 1 - Composition and calculated values of the experimental diets.

\begin{tabular}{|c|c|c|c|c|}
\hline \multirow{2}{*}{ Ingredients, \% } & \multicolumn{4}{|c|}{ Diets $^{1}$} \\
\hline & Pre-starter & Starter & Grower & Final \\
\hline Corn & 53.61 & 57.67 & 62.12 & 66.94 \\
\hline Soybean meal (46 CP\%) & 38.43 & 35.03 & 31.51 & 27.25 \\
\hline Soybean oil & 2.687 & 2.682 & 3.049 & 2.837 \\
\hline Choline chloride 60 & 0.072 & 0.064 & 0.058 & 0.043 \\
\hline Salt & 0.508 & 0.482 & 0.457 & 0.444 \\
\hline Dicalcium phosphate & 1.902 & 1.533 & 1.334 & 1.069 \\
\hline Limestone & 0.917 & 0.907 & 0.825 & 0.777 \\
\hline L-lysine & 0.283 & 0.210 & 0.193 & 0.234 \\
\hline DL-methionine & 0.357 & 0.285 & 0.253 & 0.237 \\
\hline L-Threonine & 0.106 & 0.058 & 0.039 & 0.048 \\
\hline L-Valine & 0.075 & 0.024 & 0.015 & 0.030 \\
\hline Mineral Premix ${ }^{2}$ & 0.050 & 0.050 & 0.050 & 0.050 \\
\hline Vitamin Premix ${ }^{3}$ & 0.100 & 0.100 & 0.100 & 0.050 \\
\hline Kaolin ${ }^{4}$ & 0.900 & 0.900 & - & - \\
\hline Total & 100.0 & 100.0 & 100.0 & 100.0 \\
\hline \multicolumn{5}{|l|}{ Calculated Values } \\
\hline ME (kcal/kg) & 2,950 & 3,000 & 3,100 & 3,150 \\
\hline $\mathrm{CP}(\%)$ & 22.20 & 20.80 & 19.50 & 18.00 \\
\hline Methionine + Cystine ${ }^{5}(\%)$ & 0.944 & 0.846 & 0.787 & 0.737 \\
\hline Lysine $^{5}(\%)$ & 1.310 & 1.174 & 1.078 & 1.010 \\
\hline Threonine $^{5}(\%)$ & 0.852 & 0.763 & 0.701 & 0.656 \\
\hline Valine $^{5}(\%)$ & 1.009 & 0.904 & 0.841 & 0.788 \\
\hline Calcium (\%) & 0.920 & 0.819 & 0.732 & 0.638 \\
\hline Phosphorus ${ }^{5}(\%)$ & 0.395 & 0.343 & 0.313 & 0.273 \\
\hline Sodium (\%) & 0.220 & 0.210 & 0.200 & 0.195 \\
\hline Choline (mg/kg) & 375.0 & 330.0 & 300.0 & 225.0 \\
\hline Linoleic acid (\%) & 2.72 & 2.77 & 3.07 & 3.01 \\
\hline
\end{tabular}

Pre-starter, 1 to 7 days of age; starter, 8 to 21 days of age; grower, 22 to 34 days of age; and final, 35 to 42 days of age.

${ }^{2}$ Mineral Premix (per feed kg): Cu, 9 mg; I, 1 mg; Zn, 60 mg; Fe, 30 mg; Mn, 60 mg.

${ }^{3}$ Vitamin Premix (per feed $\mathrm{kg}$ ) for phase 1 to 21 days: vitamin A, 11,000 Ul; vitamin D3, 2,000 Ul; vitamin E, 16 Ul; vitamin K3, 1.5 mg; vitamin B1, 1.2 mg; vitamin B2, 4.5 $\mathrm{mg}$; vitamin B6, 2 mg; vitamin B12, 16 mcg; folic acid, 0.4 mg; pantothenic acid, 9.2 $\mathrm{mg}$; biotin, $0.06 \mathrm{mg}$; niacin, $0.035 \mathrm{mg}$; Se, $0.25 \mathrm{mg}$.

${ }^{3}$ Vitamin Premix (per feed $\mathrm{kg}$ ) for phase 22 to 33 days: vitamin A, 9,000 Ul; vitamin D3, 1,600 Ul; vitamin E, $14 \mathrm{Ul}$; vitamin $\mathrm{K} 3,1.5 \mathrm{mg}$; vitamin $\mathrm{B} 1,1$ mg; vitamin $\mathrm{B} 2,4 \mathrm{mg}$; vitamin B6, $18 \mathrm{mg}$; vitamin B12, $12 \mathrm{mcg}$; folic acid, $0.3 \mathrm{mg}$; pantothenic acid, $8.28 \mathrm{mg}$; biotin, $0.05 \mathrm{mg}$; niacin, $0.03 \mathrm{mg}$; Se, $0.25 \mathrm{mg}$.

${ }^{3}$ Vitamin Premix (per feed $\mathrm{kg}$ ) for phase 34 to 42 days: vitamin A, 6,000 Ul; vitamin $\mathrm{D} 3,1,000 \mathrm{Ul}$; vitamin $\mathrm{E}, 10 \mathrm{Ul}$; vitamin $\mathrm{K} 3,1 \mathrm{mg}$; vitamin $\mathrm{B} 1,0.6 \mathrm{mg}$; vitamin $\mathrm{B} 2$, 2 $\mathrm{mg}$; vitamin B6, $0.8 \mathrm{mg}$; vitamin B12, $6 \mathrm{mcg}$; pantothenic acid, $7.36 \mathrm{mg}$; biotin, 0.03 $\mathrm{mg}$; niacin, $0.010 \mathrm{mg} ; \mathrm{Se}, 0,40 \mathrm{mg}$.

${ }^{4}$ The treatments were obtained by replacing kaolin with additives: diet without additives, $0.9 \%$ kaolin. Diet with probiotics, $0.1 \%$ probiotics $+0.8 \%$ kaolin. Diet with organic acids, $0.8 \%$ organic acids $+0.1 \%$ kaolin. Diet with probiotics + organic acids, $0.1 \%$ probiotics $+0.8 \%$ organic acids. Diet with antibiotics, $0.005 \%$ avilamycin + $0.03 \%$ monensin sodium $+0.865 \%$ kaolin .

${ }^{5}$ Digestible values.

performed. The prices of the ingredients $/ \mathrm{kg}$ used to elaborate the feed costs were: corn, $\$ 0.34$; soybean meal, $\$ 0.33$; soybean oil, $\$ 1.03$; choline chloride 60, $\$ 1.60$; dicalcium phosphate, $\$ 0.68$; calcitic limestone, $\$ 0.15$; L-lysine, $\$ 2.05$; DL-methionine, $\$ 3.76$; salt, $\$ 0.15$; threonine $\$ 6.06$; valine $\$ 12.16$; probiotics
$\$ 2.16$; organic acid, \$0.46; vitamin and mineral supplement for the pre-starter stage, $\$ 2.80$; starter stage, \$3.48; grower stage, \$3.56, and final stage, $\$ 1.80$. The feed cost was determined from the total feed intake per broiler multiplied by the cost of the diet used.

The price paid in the day-old chick was $\$ 0.47$ and the final value obtained in the chicken was $\$ 0.82$, whose value was obtained by means of the product between the final gross weight of the bird and the average price $/ \mathrm{kg}$ of the broiler, as practiced in the southeastern Brazil in January 2018.

Statistical Analysis System software (SAS Institute, 2012) was used to data analysis, accepting $5 \%$ of error. Residue normality was verified through the ShapiroWilk test in the UNIVARIATE procedure. The analysis of variance was calculated by the GLM procedure using orthogonal contrasts. The first contrast was designed to evaluate the main effect of probiotic: diets with probiotic against diets without probiotic (contrast 1), the second contrast evaluated the main effect of organic acids: diets with organic acids against diets without organic acids (contrast 2), and the third was used to test the effect of their interaction (contrast 1 * contrast 2). Last contrast was utilized to study the effect of the antibiotics against all the other groups.

\section{RESULTS AND DISCUSSION}

From 1 to 42 days of age, it was possible to observe that, for the performance variables studied, there was only antibiotic effect $(p<0.05)$ on the sanitary challenge imposed. The broilers showed increased weight gain (WG) and feed intake (FI), as well as better feed conversion ratio $(F C R)$ in the presence of antibiotics $(p<0.05)$ (Table 2).

The lack of effect of the additives added to the feed can be explained by the adequate experimental environment, the good management conditions, and the nutritional quality of the feed provided (Santos et al. 2005; Paz et al. 2010).

Among the treatments, there was no difference ( $p>0.05)$ for viability in the period from 1 to 42 days of age. This suggests that even with the Eimerias inoculation, the broilers have been able to react to the microbiological challenge imposed.

Studies with organic acids and probiotics have been conducted to evaluate broiler performance in an attempt to reduce or replace antibiotic growth promoters (Waldroup et al. 1995; Denli et al. 2003; Jamroz et al. 2004; Gunal et al. 2006; Lorençon et al. 
2007; Willis et al. 2007; Yalcinkayal et al. 2008; Silva et al. 2011; Ramos et al. 2014; Barbieri et al., 2015).

Differently from the findings in this study, AbdelFattah et al. (2008) added citric acid, acetic acid and lactic acid in diets for broilers in the period from 1 to 42 days and noticed an improvement in their weight gain compared to the feed without additives. Likewise, Godoi et al. (2008), adding prebiotics, symbiotics and antibiotics in broilers feed in the period from 1 to 42 days, observed improvement of up to $3.3 \%$ in weight gain $(p<0.05)$ in relation to the negative control treatment with no additives.

Research by Chowdhury et al. (2009) showed that the inclusion of $0.5 \%$ citric acid resulted in an improvement in broiler performance in the period from 1 to 35 days. Ashayerizadeh et al. (2009) also showed satisfactory results of weight gain of broilers supplemented with prebiotics, probiotics and antibiotics in relation to the negative control in the period from 1 to 42 days.

Khosravi et al. (2010), when testing the inclusion of probiotics and organic acids in broiler diets from 1 to 42 days, did not observe beneficial effects for weight gain and feed intake, which is similar to the present study, but their interaction showed a significant effect $(p<0.05)$ for feed conversion ratio. Dalólio et al. (2015), when supplementing broiler diets with enzyme complex, garlic powder and probiotics as an alternative to conventional antimicrobials, found no significant differences $(p>0.05$ ) in the variables of productive performance, which is similar to the findings in this study.

Rocha et al. (2010) found a significant effect $(p<0.05)$ of the addition of prebiotics, probiotics, organic acids and antibiotics in comparison to the control diet on the performance variables of broilers in the total period of breeding. Studies with organic acids mixtures in an attempt to improve the performance of broilers, claim to be more efficient than the antibiotic growth promoter (Enramycin) Hassan et al. (2010).

Barbieri et al. (2015) tested probiotics, organic acids and their interaction in broiler diets in the period from 1 to 21 days but did not find a satisfactory effect of these additives on performance parameters, as neither did the current research.

The economic analysis of this study shows that there was no significant effect on the profitability index (Table 3). Broilers receiving diets containing antibiotics showed higher costs, revenue, and profits. The higher costs came mainly from higher feed intake, which resulted in higher body weight of broilers fed antibiotics. In addition, it is important to mention that
Table 2 - Performance of broilers fed diets supplemented or not with probiotics, organic acids and antibiotic in the period from 1 to 42 days of age.

\begin{tabular}{|c|c|c|c|c|}
\hline \multicolumn{5}{|c|}{ Performance at 42 days of age } \\
\hline Effects $^{1}$ & $\mathrm{AWG}^{2}$ & $\mathrm{AFI}$ & FCR & VB \\
\hline \multicolumn{5}{|l|}{ Prob } \\
\hline With & 2734.3 & 4447.1 & 1.8046 & 97.50 \\
\hline $\begin{array}{l}\text { Without } \\
\text { AO }\end{array}$ & 2782.6 & 4540.1 & 1.8058 & 98.05 \\
\hline+ & 2754.5 & 4509.4 & 1.8052 & 97.77 \\
\hline- & 2762.4 & 4477.7 & 1.8052 & 97.79 \\
\hline \multicolumn{5}{|l|}{ Prob $\times A O$} \\
\hline With + & 2729.1 & 4469.7 & 1.7970 & 97.78 \\
\hline Without + & 2779.9 & 4549.2 & 1.8134 & 97.76 \\
\hline With - & 2739.4 & 4424.5 & 1.8122 & 97.22 \\
\hline $\begin{array}{l}\text { Without - } \\
\text { Antib }\end{array}$ & 2785.4 & 4531.0 & 1.7981 & 98.35 \\
\hline Presence & 2913.2 & 4673.7 & 1.7750 & 96.67 \\
\hline Absence & 2758.5 & 4493.6 & 1.8052 & 97.78 \\
\hline $\mathrm{SEM}^{3}$ & 17.5566 & 24.5312 & 0.0050 & 0.4209 \\
\hline Source of Variation & \multicolumn{4}{|c|}{ Probability } \\
\hline Prob & 0.1245 & 0.0510 & 0.9100 & 0.5778 \\
\hline OA & 0.7978 & 0.4915 & 0.9968 & 0.9839 \\
\hline Prob $\times$ OA & 0.9376 & 0.7694 & 0.1492 & 0.5643 \\
\hline Antib & 0.0001 & 0.0016 & 0.0145 & 0.3206 \\
\hline
\end{tabular}

'Prob, probiotics; OA, organic acids; Antib, antibiotic; with, presence of probiotics; without, absence of probiotics; +, presence of organic acids; - , absence of organic acids.

${ }^{2} \mathrm{AWG}$, average weight gain; $\mathrm{AFI}$, average feed intake; $\mathrm{FCR}$, feed conversion ratio; $\mathrm{VB}$, viability.

3SEM, standard error of the mean.

feed costs are quite significant in the total production cost, since about 70 to $80 \%$ of production is related to food (Teixeira et al. 2005).

Despite the highest cost, the income generated from the broilers that consumed antibiotics was quite significant and superior to the income from broilers that did not, surpassing expenses and leading to higher profits, making antibiotic treatment the most economically viable.

Chowdhury et al. (2009) demonstrated that the lowest production cost of broilers was found in those fed with organic acids, followed by antibiotics, negative control (without additives), and the interaction among them.

When evaluating broiler productive performance using enzymatic complexes with nutritional matrices in their diets, Pasquali et al. (2017) observed that they did not favor the economic viability of broilers in the period from 1 to 42 days.

According to Garcia \& Ferreira Filho (2005), the large poultry farms are located in the central-west and south of Brazil, and it would be easier to reduce costs and expand the Brazilian economy more and more 
in the poultry sector. This is because a large part of the animal nutrition basis, such as corn and soybean meal, comes from these regions, which are the largest domestic producers.

As the price of commodities always varies, the interesting thing is to pay attention to the forms that allow a monitoring of production costs (Melo et al., 2008), so that the producer has a better financial return of his production system.

\section{CONCLUSION}

Under the challenge conditions imposed in this research, organic acids and probiotic, isolated or associated, do not present satisfactory effects on broiler performance and economic viability to be characterized as potential substitutes for antibiotic growth promoters.

\section{ACKNOWLEDGMENTS}

We thank the São Paulo Research Foundation (FAPESP, Brazil) for the scholarship (Proc. 2013/15653$0)$. We also thank Nutriacid/Btech for donating the probiotic and the organic acids.

\section{REFERENCES}

Ayasan T. Effects of dietary inclusion of protexin (probiotic) on hatchability of Japanese quails. Indian Journal Animal Science 2013;83:78-81.

Abdel-Fattah SA, El-Sanhoury MH, Mednay NM, Abdelazeem F. Thyroid activity, some blood constituents, organs morphology and performance of broilers chicks fed supplemental organic acids. International Journal of Poultry Science 2008;7:215-222.

Ashayerizadeh A, Dabiri N, Ashayerizadeh O, Mirzadeh KH, Roshanfekr $\mathrm{H}$, Mamooee M. Effect of dietary antibiotic, probiotic and prebiotic as growth promoters, on growth performance, carcass characteristics and hematological indices of broiler chickens. Pakistan Journal of Biological Science 2009;12: 52-57.

Barbieri A, Polycarpo GV, Cardoso RGA, Silva KM, Dadalt JC, Madeira AMBN, Souza RLM, Alburquerque R, Cruz-Polycarpo VC. Effect of probiotic and organic acids in an attempt to replace the antibiotics in diets of broiler chickens challenged with Eimeria spp. International Journal of Poultry Science 2015;14:606-614.

Chowdhury R, Islam KMS, Khan MJ, Karim MR, Haque MN, Khatun M, Pesti GM. Effect of citric acid, avilamycin, and their combination on the performance, tibia ash, and immune status of broilers. Poultry Science 2009;88:1616-1622.

Dalólio FS, Moreira J, Valadares LR, Nunes PB, Vaz DP, Pereira HJ, Pires AV, Cruz PJR. Aditivos alternativos ao uso de antimicrobianos na alimentação de frangos de corte. Revista Brasileira de Agropecuária Sustentável 2015;5:86-94.

Dibner JJ, Buttin P. Use of organic acids as a model to study the impact of gut microflora on nutrition and metabolism. Journal of Applied Poultry Research 2002;11: 453-463.

Table 3 - Economic analysis of breeding broilers fed diets supplemented or not with probiotic, organic acids, and antibiotic.

\begin{tabular}{|c|c|c|c|c|c|c|c|c|c|c|}
\hline \multirow{3}{*}{ Effects $^{1}$} & & \multicolumn{9}{|c|}{ Economic analysis ${ }^{2}$} \\
\hline & & \multicolumn{4}{|c|}{ Costs $(\$)$} & \multicolumn{2}{|c|}{ Revenue (\$) } & \multicolumn{3}{|c|}{ Profit (\$) } \\
\hline & & Feed & Other & Bird & Total & Bird & Total & Bird & Total & Index \\
\hline \multirow{2}{*}{ Prob } & with & 128.1 & 22.0 & 6.6 & 196.6 & 7.5 & 219,1 & 0.94 & 22.4 & 10.2 \\
\hline & without & 131.2 & 22.5 & 6.7 & 200.0 & 7.6 & 224.2 & 0.95 & 24.2 & 10.8 \\
\hline \multirow{2}{*}{ OA } & + & 130.6 & 22.4 & 6.7 & 199.4 & 7.6 & 221.3 & 0.90 & 21.9 & 9.9 \\
\hline & - & 128.7 & 22.1 & 6.6 & 197.3 & 7.6 & 221.9 & 0.99 & 24.7 & 11.1 \\
\hline \multirow{4}{*}{ Prob $\times \mathrm{OA}$} & with + & 130.4 & 22.3 & 6.6 & 199.2 & 7.5 & 219.3 & 0.83 & 20.0 & 9.1 \\
\hline & without + & 130.7 & 22.4 & 6.7 & 199.5 & 7.6 & 223.3 & 0.96 & 23.8 & 10.6 \\
\hline & with - & 125.8 & 21.7 & 6.5 & 194.0 & 7.5 & 218.8 & 1.04 & 24.8 & 11.3 \\
\hline & without - & 131.6 & 22.5 & 6.7 & 200.5 & 7.6 & 225.0 & 0.94 & 24.5 & 10.9 \\
\hline \multirow{2}{*}{ Antib } & presence & 134.9 & 22.9 & 6.8 & 204.2 & 8.0 & 231.3 & 1.20 & 27.0 & 11.6 \\
\hline & absence & 129.6 & 22.2 & 6.6 & 198.3 & 7.6 & 221.6 & 0.95 & 23.3 & 10.5 \\
\hline $\mathrm{SEM}^{3}$ & & 1.0124 & 0.1276 & 0.0378 & 1.1397 & 0.0475 & 1.4684 & 0.0379 & 1.0381 & 0.4245 \\
\hline \multicolumn{11}{|l|}{ Probability } \\
\hline Prob & & 0.1582 & 0.1555 & 0.1608 & 0.1584 & 0.1216 & 0.0914 & 0.8135 & 0.4599 & 0.5588 \\
\hline $\mathrm{OA}$ & & 0.3719 & 0.3698 & 0.3735 & 0.3715 & 0.7788 & 0.8199 & 0.2470 & 0.2346 & 0.2075 \\
\hline Prob $\times O A$ & & 0.1910 & 0.1914 & 0.1931 & 0.1910 & 0.9520 & 0.7071 & 0.1623 & 0.3846 & 0.3117 \\
\hline Antib & & 0.0317 & 0.0318 & 0.0323 & 0.0318 & 0.0001 & 0.0063 & 0.0175 & 0.1535 & 0.2877 \\
\hline
\end{tabular}

'Prob, probiotic; OA, organic acids; Antib, antibiotic.

${ }^{2}$ Costs: Feed (total feed cost), Other (other costs), Bird (costs per bird), Total (total costs). Revenue: Bird (revenue per bird), Total (total revenue). Profit: Bird (profit per bird), Total (total profit). Index (profitability index).

3SEM, standard error of the mean. 
Denli M, Okan F, Çelik K. Effect of Dietary Probiotic, Organic Acid and Antibiotic Supplementation to Diets on Broiler Performance and Carcass Yield. Pakistan Journal of Nutrition 2003;2:89-91.

Garcia LAF, Ferreira Filho JBS. Economias de escala na produção de frangos de corte no Brasil. Revista de Economia e Sociologia Rural 2005;43:465483.

Godoi MJS, Albino LFT, Rostagno HS, Gomes PC, Barreto SLT, Junior JGV. Utilização de aditivos em rações formuladas com milho normal e de baixa qualidade para frangos de corte. Revista Brasileira de Zootecnia 2008;37:1005-1011

Gonzales E, Mello HHC, Café MB. Uso de antibióticos promotores de crescimento na alimentação e produção animal. Universiddae Federal de Goiás: Dossiê Pecuária; 2012. p.13.

Gunal M, Yayli G, Kaya O, Karahan N, Sulak O. The Effects of Antibiotic Growth Promoter, Probiotic or Organic Acid Supplementation on Performance, Intestinal Microflora and Tissue of Broilers. International Journal of Poultry Science 2006;5: 149-155.

Hassan HMA, Mohamed MA, Youssef AW, Hassan ER. Effect of using organic acids to substitute antibiotic growth promoters on performance and intestinal microflora of broilers. Asian-Australasian Journal Animal Science 2010:23:1348-1353.

Huyghebaert G, Ducatelle R, Van Immerseel F. An update on alternatives to antimicrobial growth promoters for broilers. Veterinary Journal 2011;187:182-188.

Jamroz D, Wiliczkiewicz A, Orda J, Wertelecki T, Skorupinska J. Response of broiler chickens to the diets supplemented with feeding antibiotic or mannan-oligosaccharides. Electronic Journal of Polish Agricultural Universities 2004;7:1-6.

Kabir SML. The Role of Probiotics in the Poultry Industry. International Journal of Molecular Sciences 2009;10:3531-3546.

Kaur IP, Chopra K, Saini A. Probiotics: potential pharmaceutical applications. European Pharmaceutical Science 2002;15:1-9.

Khosravi A, Boldaji F, Dastar B, Hasani S. Immune response and performance of broiler chicks fed protexin and propionic acid. International Journal of Poultry Science 2010;9:188-191.

Kelley TR, Pancorbo OC, Merka WC, Barnhart HN. Antibiotic resistance of bacterial litter isolates. Poultry Science 1998;77:243-247.

Kim and Kim. Dietary organic acids for broiler chickens: A review. Revista Colombiana de Ciencias Pecuarias 2015;28:109-123.

Kipper M, Andretta I, Lehnen CR, Lovatto PA, Monteiro SG. Meta-analysis of the performance variation in broilers experimentally challenged by Eimeria spp. Veterinary Parasitology 2013;196:77-84.

Lana GRQ. Avicultura. Campinas: Livraria e Editora Rural; 2000.

Langhout P. New additives for broiler chickens. World Poultry 2000; 16 : 22-27.

Loddi MM, Gonzales E, Takita TS, Mendes AA, Roça RO. Uso de probiótico e antibiótico sobre o desempenho, o rendimento e a qualidade de carcaça de frangos de corte. Revista Brasileira de Zootecnia 2000;29:1124-1131.

Lorençon L, Nunes RV, Pozza PC, Pozza MSS, Appelt MD, Silva WTM. Utilização de promotores de crescimento para frangos de corte em rações fareladas e peletizadas. Acta Scientiarum Animal Sciences 2007;29:151-158.

Martin NB, Serra R, Oliveira MDM, Angelo JA, Okawa H. Sistema "CUSTAGRI": sistema integrado de custos agropecuários. São Paulo: IEA/SAA; 1997. p1-75.
Melo CO Silva GH, Esperancini MST. Análise econômica análise econômica da produção de frango... da produção de frango de corte sob 1919 condições de risco no estado do paraná. Ciência e Agrotecnologia 2008;32:1919-1926.

Mountzouris KC, Tsirtsikos P, Kalamara E, Nitsch S, Schatzmayr G, Fegeros $K$. Evaluation of the efficacy of a probiotic containing Lactobacillus, Bifidobacterium, enterococcus and pediococcus strains in promoting broilers performance and modulation cecal microflora composition and metabolic activities, Poultry Science 2007;86:309-317.

Pasquali GAM, Oliveira RF, Aiello PAB, Polycarpo GV, Crivellari R, CruzPolycarpo VC. Performance and economic viability of broiler chicken fed diets with multienzyme complexes. Acta Scientiarum Animal Sciences 2017;39:91-96.

Paz AS, Abreu RD, Costa MCMM. Aditivos promotores de crescimento na alimentação de frangos de corte. Revista Brasileira de Saúde e Produção Animal 2010;11:395-402.

Ramos LSN, Lopes JB, Ribeiro MN, Silva FES, Merval RR, Albuquerque DMN. Aditivos alternativos a antibióticos para frangos de corte no período de 22 a 42 dias de idade. Revista Brasileira de Saúde e Produção Animal 2014;15:897-906

RochaAP, Abreu RD, CostaMCMM. Prebióticos, ácidosorgânicose probióticos em rações para frangos de corte. Revista Brasileira de Saúde e Produção Animal 2010;11:793-801.

Roe MT, Pillai SD. Monitoring and Identifying Antibiotic Resistance Mechanisms in Bacteria. Poultry Science 2003;82:622-626.

Rostagno HS, Albino LFT, Donzele JL, Gomes PC, Oliveira RF, Lopes DC, Ferreira AS, Barreto SLT, Euclides RF. Tabelas brasileiras para aves e suínos: composição de alimentos e exigências nutricionais. Viçosa: UFV; 2011. $252 \mathrm{p}$.

Rufino JPF, Cruz FGG, Miller WPM, Melo RD, Feijó JC, Chagas EO. Análise econômica da inclusão de farinha do resíduo de tucumã (Astrocaryum vulgare, Mart) na alimentação de poedeiras comerciais. Revista Brasileira de Saúde e Produção Animal 2015,16:1-9.

Sanders ME. Probiotics: Definition, Sources, Selection, and Uses. Clinical Infectious Diseases 2008; 46: 58-61.

Santos EC, Teixeira AS, Freitas RTF, Rodrigues PB, Dias ES, Murgas LDS Uso de aditivos promotores de crescimento sobre o desempenho, características de carcaça e bactérias totais do intestino de frangos de corte. Ciência e Agrotecnologia 2005; 29:223-231.

Silva TRG, Nascimento, MCO, Silva NC. Uso de óleos essenciais na dieta de suínos em substituição aos antimicrobianos. Acta Veterinaria Brasilica 2010;4:70-73.

Silva WTM, Nunes RV, Pozza PC. Avaliação de inulina e probiótico para frangos de corte. Acta Scientiarum Animal Sciences 2011;33:19-24.

M'Sadeq SA, Wu S, Swick RA, Choct M. Towards the control of necrotic enteritis in broiler chickens with in-feed antibiotics phasing-out worldwide. Animal Nutrition 2015, 1:1-11.

Shirley MW, Ivens A, Gruber A, Madeira AMBN, Wan KL, Dear PH, Tomley FM. The Eimeria genome projects: a sequence of events. Trends in Parasitology 2004;20: 199-201.

Sorum $\mathrm{H}$, Sunde M. Resistance to antibiotics in the normal flora of animals. Veterinary Research 2001;32:182-188.

SAS- Statistical Analysis System. User's guide. Version 9.2. Cary: Statistical Analysis System Institute; 2012.

Teixeira CA, Oliveira Filho D, Lacerda Filho AF, Martins JH. Racionalização do uso de forca motriz em fábrica de ração. Engenharia Agrícola 2005:25:330-340 
Van Immerseel F, Russel JB, Flythe MD, Gantois I, Timbermont L, Pasmans F, Haesebrouck F, Ducatelle R. The use of organic acids to combat salmonella in poultry: a mechanistic explanation of the efficacy. Avian Pathology 2006;35:182-188.

Yalcinkayal H, Gungori T, Bafialani M, Erdem E. Mannan oligosaccharides (MOS) from saccharomyces cerevisiae in broilers: Effects on performance and blood biochemistry. Turkish Journal Veterinary Animal Science 2008;32:43-48.

Waldroup A, Kaniawati S, Mauromoustakos A. Performance characteristics and microbiological aspects of broilers fed diets supplemented with organic acids. Journal of Food Protection 1995;58:482-489.
Williams RBA. Compartmentalized model for the estimation of the cost of coccidiosis to the world's chicken production industry. International Journal of Parasitology 1999; 29:1209-1229.

Williams RB. Intercurrent coccidiosis and necrotic enteritis of chickens: rational, integrated disease management by maintenance of gut integrity. Avian Pathology 2005; 34:159-180.

Willis WL, Isikuemhen OS, Ibrahim SA. Performance assessment of broiler chickens given mushroom extract alone or in combination with probiotics. Poultry Science 2007;86:1856-1860. 
